\title{
NO GAS DOPING OF ZnO FILMS USING Ir HOT-WIRE IN CATALYTIC REACTION-ASSISTED CHEMICAL VAPOR DEPOSITION
}

\section{RYUTA IBA ${ }^{1}$, YUKI ADACHI ${ }^{1}$, ARIYUKI KATO ${ }^{1}$, KOICHIRO OISHI $^{2}$, HIRONORI KATAGIRI ${ }^{2}$ and KANJI YASUI ${ }^{1}$}

${ }^{1}$ Nagaoka University of Technology

Nagaoka

Niigata, 940-2188

Japan

e-mail: kyasui@vos.nagaokaut.ac.jp

${ }^{2}$ National Institute of Technology

Nagaoka College

Nagaoka

Niigata, 940-8532

Japan

\begin{abstract}
Nitrogen doping of $\mathrm{ZnO}$ films by the decomposition of $\mathrm{NO}$ gas using a heated Ir wire during film growth was attempted through the reaction between dimethylzinc (DMZn) and high-temperature $\mathrm{H}_{2} \mathrm{O}$. High-temperature $\mathrm{H}_{2} \mathrm{O}$ was produced by the Pt-catalyzed reaction between $\mathrm{H}_{2}$ and $\mathrm{O}_{2}$. Although p-type $\mathrm{ZnO}$ films were not obtained, the residual carrier concentration decreased upon the addition of NO gas. In X-ray photoelectron spectra, multiple overlapping $\mathrm{N}-1$ s peaks were observed from $395 \mathrm{eV}$ to $408 \mathrm{eV}$. By deconvoluting the spectra, components such as Zn-N, N-H, N-N, and $\mathrm{N}_{x} \mathrm{O}_{y}$ were identified. The relative intensity of the $\mathrm{Zn}-\mathrm{N}$ peak at $395.5 \mathrm{eV}-396.8 \mathrm{eV}$ increased when a heated Ir wire was used to decompose the NO gas.
\end{abstract}

Keywords and phrases: $\mathrm{ZnO}$, catalytic reaction, Ir hot-wire, nitrogen doping.

Received March 26, 2019

(ㄷ) 2019 Scientific Advances Publishers 


\section{Introduction}

Zinc oxide $(\mathrm{ZnO})$ has drawn considerable interest owing to its potential applications in the ultraviolet wavelength range [1]. $\mathrm{ZnO}$ offers significant advantages for optoelectronic applications, such as lightemitting diodes and laser diodes in the ultraviolet range, because of their large binding energy $(\sim 60 \mathrm{meV})[2]$. We have previously developed a new chemical vapor deposition (CVD) method for $\mathrm{ZnO}$ film growth using a catalytic reaction between hydrogen and oxygen gases on $\mathrm{Pt}$ nanoparticles [3]. In order to fabricate optical emission devices, n-type and p-type $\mathrm{ZnO}$ crystals are required [4]. Doping with $\mathrm{Al}$ and $\mathrm{Ga}$ has been attempted by many groups, resulting in high-quality, highly conductive $\mathrm{n}$-type $\mathrm{ZnO}$ films [5-10]. Although n-type $\mathrm{ZnO}$ with low resistivity has been grown by the doping of donor impurities, reproducible fabrication of p-type $\mathrm{ZnO}$ is very difficult. In order to fabricate $\mathrm{p}$-type $\mathrm{ZnO}$, a high concentration of nitrogen atoms is required. Nitrogen doping of $\mathrm{ZnO}$ by CVD can be achieved through the addition of nitrogen oxide gases. For some cases of nitrogen doping, the addition of $\mathrm{N}_{2} \mathrm{O}$ and $\mathrm{NO}$ gases has been considered [11-14]. However, the addition of $\mathrm{N}_{2} \mathrm{O}$ during our CVD method did not result in nitrogen doping [15]. NO is more reactive than $\mathrm{N}_{2} \mathrm{O}$. Gases can be decomposed effectively on heated refractory metal surfaces. For the decomposition of NO, refractory metals that can withstand oxygen atmosphere, such as platinum $(\mathrm{Pt})$ and iridium (Ir), are suitable [16].

In the present work, we have tried nitrogen doping using $\mathrm{NO}$ gas and investigated the effect on NO decomposition by a heated Ir wire during $\mathrm{ZnO}$ film growth.

\section{Experimental}

The CVD apparatus used in this study had the same structure as that reported in a previous paper [3], except for the addition of an Ir wire, as shown in Figure $1 . \mathrm{H}_{2}$ and $\mathrm{O}_{2}$ gases were introduced into a catalyst 
cell containing a Pt-dispersed $\mathrm{ZrO}_{2}$ catalyst, following which the temperature of the catalyst cell quickly rose above $1000^{\circ} \mathrm{C}$, owing to the exothermic reaction between $\mathrm{H}_{2}$ and $\mathrm{O}_{2}$ over the catalyst. After $10 \mathrm{~min}$ of the introduction of $\mathrm{H}_{2}$ and $\mathrm{O}_{2}$, the catalytic cell temperature stabilized, at which time the shutter located between the skimmer cone and the substrate holder was opened. The skimmer cone between the $\mathrm{H}_{2} \mathrm{O}$ nozzle and the substrate served to selectively direct only highvelocity $\mathrm{H}_{2} \mathrm{O}$ molecules to the substrate. The generated hightemperature $\mathrm{H}_{2} \mathrm{O}$ molecules were ejected from a de Laval nozzle into the reaction zone in the chamber and allowed to collide with DMZn gas ejected from another small nozzle (inner diameter: $1.0 \mathrm{~mm}$ ). The $\mathrm{H}_{2}$ and $\mathrm{O}_{2}$ gas flow rates during growth were set at 400 and $130 \mathrm{sccm}$, respectively. The DMZn gas flow rate was adjusted so as to maintain a partial pressure of $4.6 \times 10^{-3} \mathrm{~Pa}$. Epitaxial $\mathrm{ZnO}$ films were grown on a-plane sapphire substrates at a substrate temperature of $500^{\circ} \mathrm{C}$ for 60 min without a buffer layer. The NO gas pressure was varied in the range from $1.0 \times 10^{-3} \mathrm{~Pa}$ to $3.0 \times 10^{-1} \mathrm{~Pa}$. The total reaction gas pressure in the chamber during deposition ranged between $0.4 \mathrm{~Pa}$ and $0.8 \mathrm{~Pa}$, depending on the NO gas pressure. An Ir wire, $0.5 \mathrm{~mm}$ in diameter and $50 \mathrm{~mm}$ in length, was heated at $1200^{\circ} \mathrm{C}$. The pressure was measured by using an ionization vacuum gauge, however, the measured value was not multiplied by the correction factor for the specific gas species. The sapphire substrates were degreased by washing with methanol and acetone in an ultrasonic cleaner, etched with a $\mathrm{H}_{2} \mathrm{SO}_{4} / \mathrm{H}_{3} \mathrm{PO}_{4}$ solution, rinsed with ultrapure water, and finally, set on a substrate holder in the CVD chamber. The film thicknesses obtained were 2.0-3.0 $\mu \mathrm{m}$. The crystallinity and crystal orientation for each $\mathrm{ZnO}$ film were characterized by X-ray diffraction (XRD, Bragg-Brentano configuration, $\omega-2 \theta$ scan and $\omega$ rocking curve) using $\mathrm{Cu}-\mathrm{K} \alpha_{1}$ radiation (Rigaku, Smart Lab). The surface morphology was observed by using atomic force microscopy 
(AFM, Shimadzu 9500J2). The carrier concentration of the $\mathrm{ZnO}$ films was determined by the van der Pauw method (ECOPIA, HMS-5000) under a magnetic field of $0.57 \mathrm{~T}$ at room temperature. The incorporation of nitrogen atoms and their bonding structure in the $\mathrm{ZnO}$ films were evaluated from N-1s spectra and their deconvolution measured by an X-ray photoelectron spectrometer (XPS, JEOL JPS-9010TR).

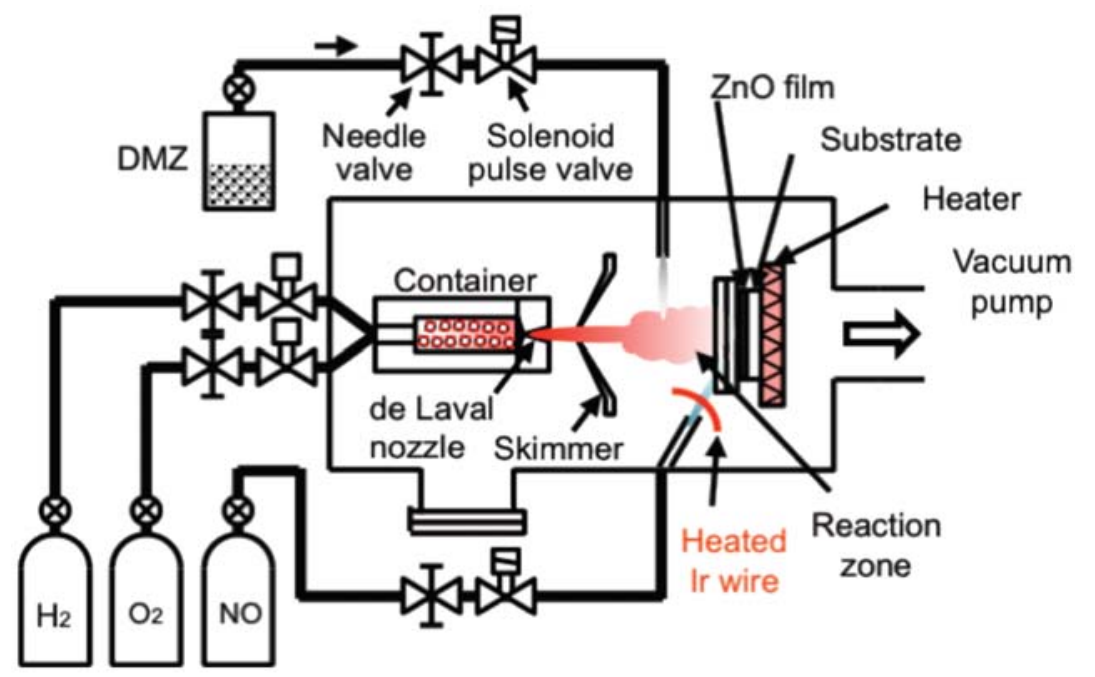

Figure 1. Schematic of CVD apparatus used in this study.

\section{Results and Discussion}

In the XRD patterns of all films, an intense (0002) peak at $2 \theta=34.44^{\circ}$, associated with c-plane $\mathrm{ZnO}$, was observed (not shown). Figure 2 shows the $\omega$-rocking curves of the $\mathrm{ZnO}$ (0002) peak for undoped and NO-doped $\mathrm{ZnO}$ films. The FWHM of the $\omega$-rocking curve of $\mathrm{ZnO}$ (0002) also increased with increasing NO pressure, which indicates the degradation of crystal orientation along the c-axis upon the addition of NO gas. 


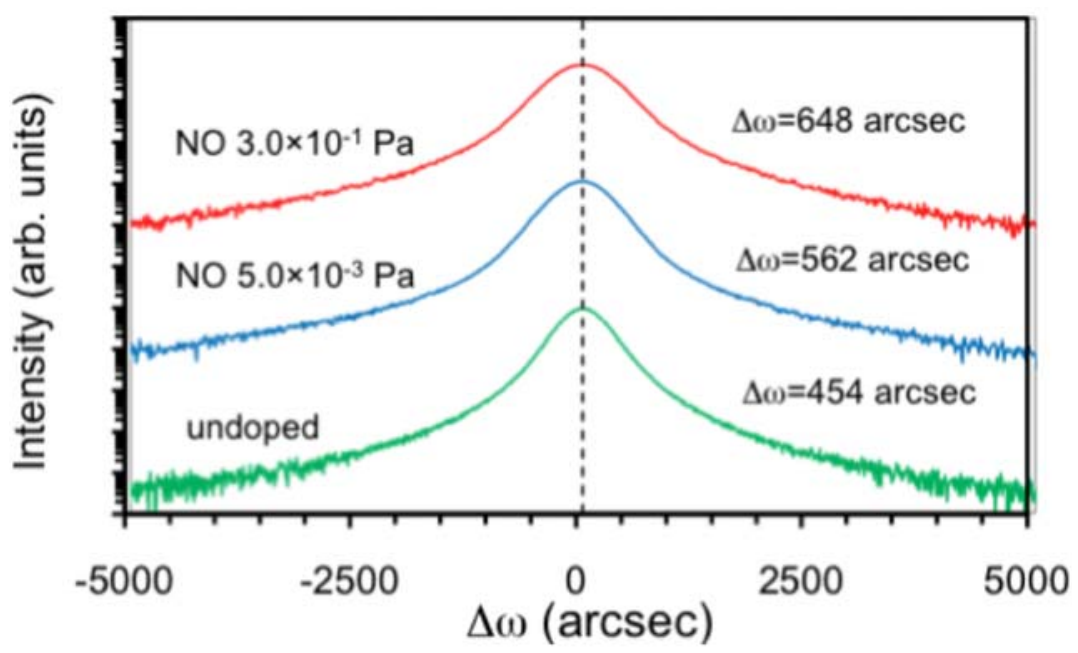

Figure 2. $\mathrm{ZnO}$ (0002) $\omega$-rocking curves for the films grown with and without NO gas.

Figure 3 shows AFM images of the surface of $\mathrm{ZnO}$ films grown with and without NO gas. Although hexagonal facets can be observed for all films, the facet dimensions are small for the $\mathrm{ZnO}$ films grown with $\mathrm{NO}$ gas. This indicates that the crystallite size of the $\mathrm{ZnO}$ film decreased during growth in the presence of NO. 


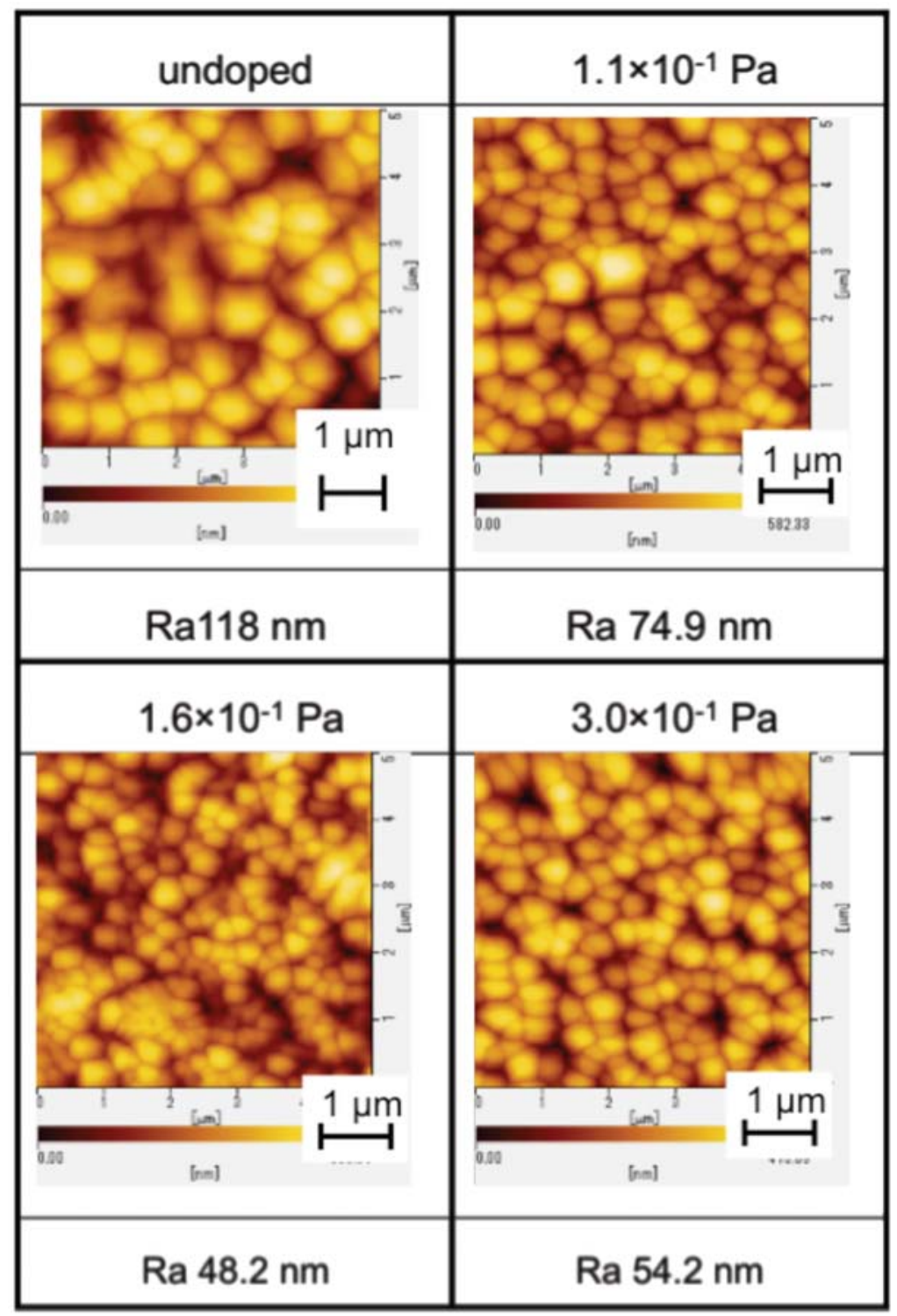

Figure 3. Atomic force microscopy images of $\mathrm{ZnO}$ films grown at various NO gas pressures $(5 \times 5 \mu \mathrm{m})$. 
Figure 4 shows the dependence of the residual carrier (electron) density in the NO gas pressure measured by Hall effect measurement. All films showed the n-type characteristics. Although the residual carrier concentration was reduced by the addition of NO as shown in this figure, the $\mathrm{ZnO}$ films with low carrier concentrations were obtained at relatively low NO gas pressures of $2.5 \times 10^{-3} \mathrm{~Pa}$ to $5.0 \times 10^{-3} \mathrm{~Pa}$.

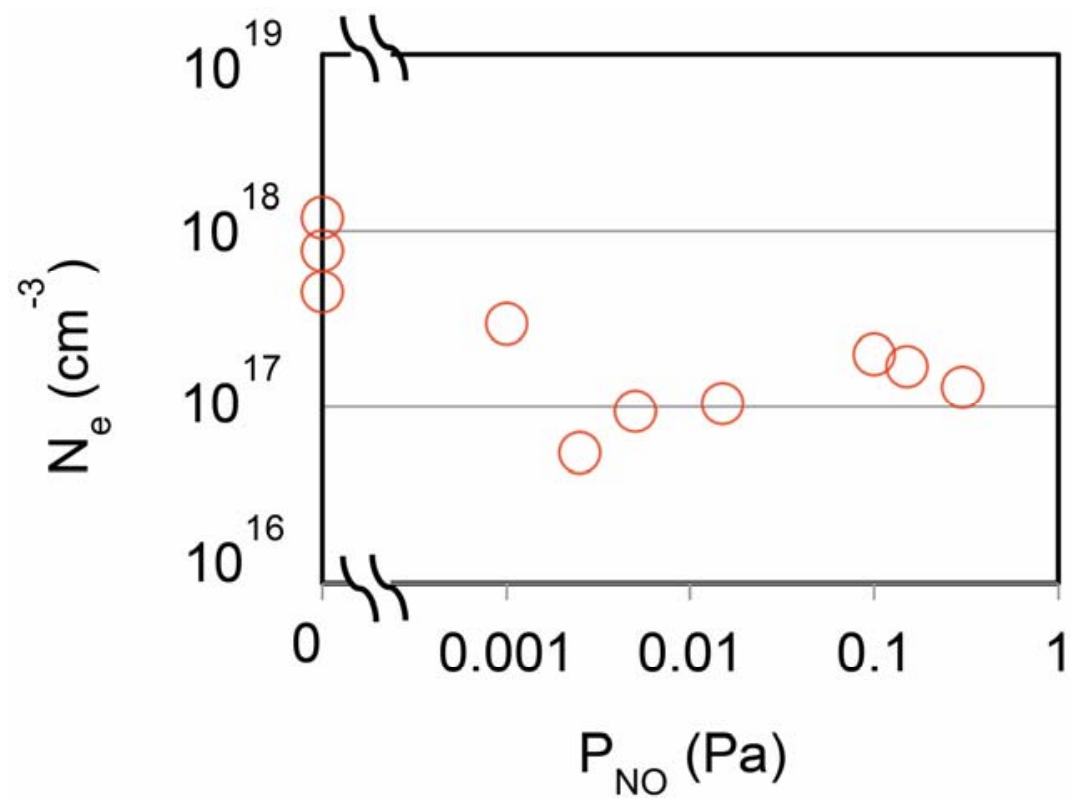

Figure 4. Dependence of carrier concentration of $\mathrm{ZnO}$ films on the NO gas pressure.

In the X-ray photoelectron spectra, multiple overlapping $\mathrm{N}$-1s peaks were observed from $395 \mathrm{eV}$ to $408 \mathrm{eV}$, as shown in Figure 5. Figure 5(a) is a result of the $\mathrm{ZnO}$ film grown with unheated Ir wire. On the other hand, Figures 5(b) and (c) are the results of them grown with heated Ir wire. By deconvolving the spectra, components such as $\mathrm{Zn}-\mathrm{N}, \mathrm{N}-\mathrm{H}, \mathrm{N}-\mathrm{N}, \mathrm{NO}_{2}$ and $\mathrm{N}_{2} \mathrm{O}$ were identified [17]. The relative intensity of the all $\mathrm{N}-1 \mathrm{~s}$ components increased when the heated Ir wire was used. In particular, the relative intensity of the Zn-N peak became large at NO pressures of $2.5 \times 10^{-3} \mathrm{~Pa}$ with the heated Ir wire. 

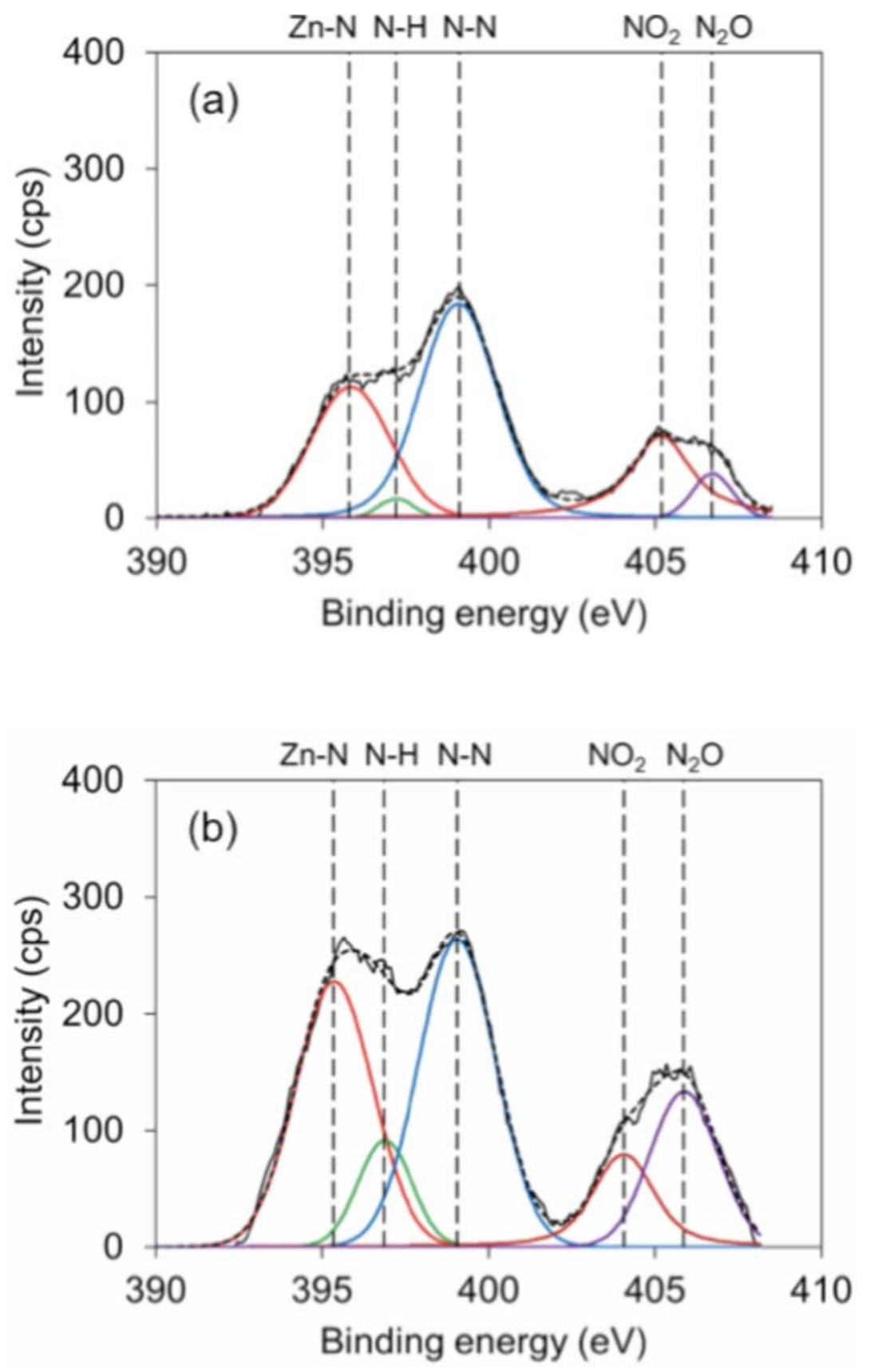
NO GAS DOPING OF ZnO FILMS USING Ir ...

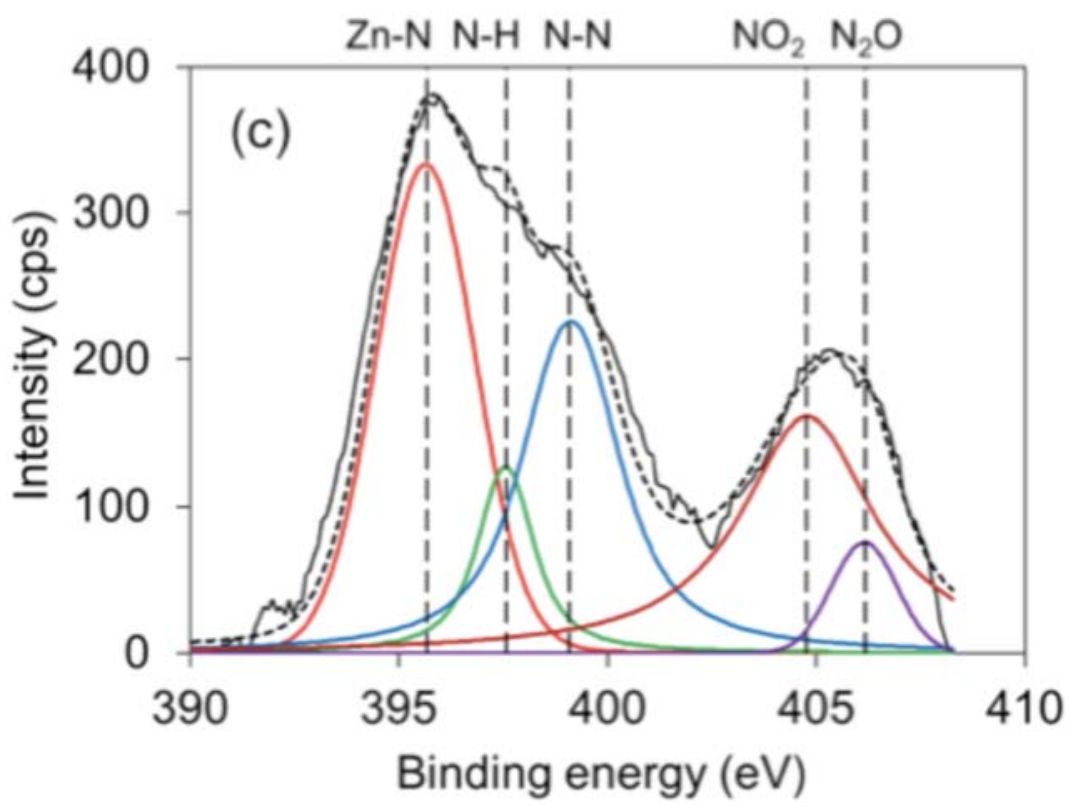

Figure 5. XPS spectra of $\mathrm{N}-1 \mathrm{~s}$ region of $\mathrm{ZnO}$ films grown with Ir wire. (a) NO gas added sample $\left(1.3 \times 10^{-1} \mathrm{~Pa}\right.$, without heating of Ir wire), (b) NO gas added sample $\left(1.3 \times 10^{-1} \mathrm{~Pa}\right.$, with heated $\mathrm{Ir}$ wire), and (c) NO gas added sample $\left(5.0 \times 10^{-3} \mathrm{~Pa}\right.$, with heated Ir wire $)$.

Figure 6 shows the relative integrated intensity ratios of the $\mathrm{Zn}-\mathrm{N}$, $\mathrm{N}-\mathrm{N}$ and $\mathrm{N}_{\mathrm{x}}-\mathrm{O}_{\mathrm{y}}\left(\mathrm{NO}_{2}+\mathrm{N}_{2} \mathrm{O}\right)$ components. The relative integrated intensity ratio of the $\mathrm{Zn}-\mathrm{N}$ peak was large at a NO gas pressure at $2.5 \times 10^{-3} \mathrm{~Pa}$, as shown in Figure 6 . The $\mathrm{Zn}-\mathrm{N}$ component is ascribable to the $\mathrm{N}$ atoms that substitute the $\mathrm{O}$ atoms in the $\mathrm{ZnO}$ crystal, which act as acceptors. On the other hand, the $\mathrm{N}-\mathrm{N}$ component is ascribable to the $\mathrm{N}$ atoms that act as shallow double-donors [18]. In order to obtain the p-type $\mathrm{ZnO}$, therefore, the higher-density $\mathrm{Zn}-\mathrm{N}$ bonds and lower-density $\mathrm{N}-\mathrm{N}$ bonds are required. The X-ray photoelectron spectra revealed that the formation of $\mathrm{Zn}-\mathrm{N}$ bonds in the $\mathrm{ZnO}$ films using a heated Ir wire during film growth, in particular at $\mathrm{NO}$ gas pressures from $2.5 \times 10^{-3} \mathrm{~Pa}$ 
to at $5.0 \times 10^{-3} \mathrm{~Pa}$, was effective. At high NO gas pressure higher than $1.0 \times 10^{-1} \mathrm{~Pa}$, total gas pressure in the chamber becomes high. Nitrogen radicals generated on the heated Ir wire would be deactivated by the scattering with gas molecules in the area between the Ir and the substrate. The deactivation may result in the decrease of the $\mathrm{Zn}-\mathrm{N}$ bond concentration.

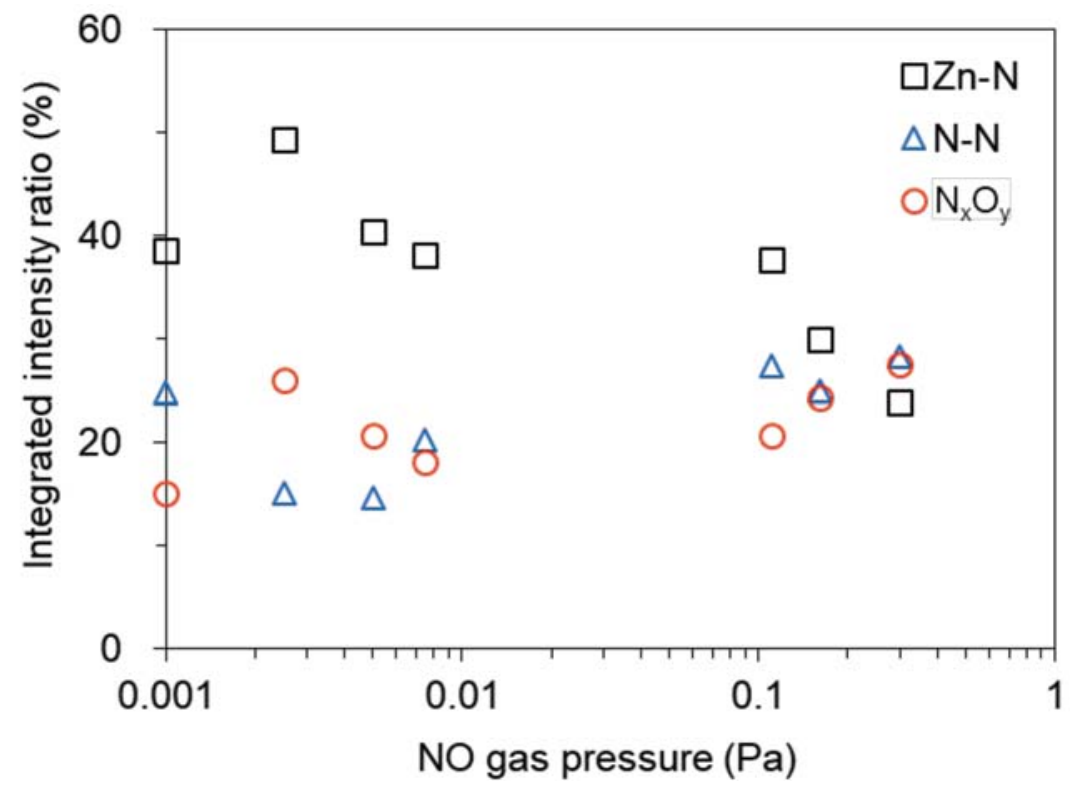

Figure 6. Relative integrated intensity ratios of $\mathrm{Zn}-\mathrm{N}, \mathrm{N}-\mathrm{N}$ and $\mathrm{N}_{\mathrm{x}}-\mathrm{O}_{\mathrm{y}}$ components.

\section{Conclusion}

The effect of a heated Ir wire during $\mathrm{ZnO}$ film growth on nitrogen doping by decomposition of NO gas was investigated by CVD using hightemperature $\mathrm{H}_{2} \mathrm{O}$ generated by the Pt-catalyzed reaction between $\mathrm{H}_{2}$ and $\mathrm{O}_{2}$. Upon the addition of $\mathrm{NO}$ gas, the crystal orientation along the c-axis deteriorated. Although no p-type $\mathrm{ZnO}$ films were obtained, 
nitrogen incorporation increased when the heated Ir wire was used. The relative intensity of the $\mathrm{Zn}-\mathrm{N}$ component in the $\mathrm{N}-1$ s peak became large at NO gas pressures from $2.5 \times 10^{-3} \mathrm{~Pa}$ to at $5.0 \times 10^{-3} \mathrm{~Pa}$. Thus, it was found that the use of the heated Ir wire during film growth was effective for the nitrogen doping.

\section{Acknowledgements}

This work was supported in part by a Grant-in-Aid for Scientific Research (No. 16H03869) from the Japan Society for the Promotion of Science.

\section{References}

[1] Ü. Özgür, Y. I. Alivov, C. Liu, A. Teke, M. A. Reshchikov, S. Doğan, V. Avrutin, S.-J. Cho and H. Morkoç, A comprehensive review of $\mathrm{ZnO}$ materials and devices, Journal of Applied Physics 98(4) (2005); Article 041301.

DOI: https://doi.org/10.1063/1.1992666

[2] B. K. Meyer, H. Alves, D. M. Hofmann, W. Kriegseis, D. Forster, F. Bertram, J. Christen, A. Hoffmann, M. Straßburg, M. Dworzak, U. Haboeck and A. V. Rodina, Bound exciton and donor-acceptor pair recombinations in $\mathrm{ZnO}$, Physica Status Solidi (b) 241(2) (2004), 231-260.

DOI: https://doi.org/10.1002/pssb.200301962

[3] K. Yasui, N. Yamaguchi, E. Nagatomi, S. Satomoto and T. Kato, Electrical properties of zinc oxide thin films deposited using high-energy $\mathrm{H}_{2} \mathrm{O}$ generated from a catalytic reaction on platinum nanoparticles, MRS Symp. Pro. 1494 (2013), 127-132.

DOI: https://doi.org/10.1557/opl.2013.240

[4] A. Tsukazaki, M. Kubota, A. Ohtomo, T. Onuma, K. Ohtani, H. Ohno, S. F. Chichibu and M. Kawasaki, Blue light-emitting diode based on $\mathrm{ZnO}$, Japanese Journal of Applied Physics, Part 2 44(20-23) (2005), L643-L645.

DOI: https://doi.org/10.1143/JJAP.44.L643

[5] S. Y. Myong, S. J. Baik, C. H. Lee, W. Y. Cho, and K. S. Lim, Extremely transparent and conductive $\mathrm{ZnO}: \mathrm{Al}$ thin films prepared by photo-assisted metalorganic chemical vapor deposition (photo-MOCVD) using $\mathrm{AlCl}_{3}\left(6 \mathrm{H}_{2} \mathrm{O}\right)$ as new doping material, Japanese Journal of Applied Physics, Part 2 36(8B) (1997), L1078-L1081.

DOI: https://doi.org/10.1143/JJAP.36.L1078 
[6] B. M. Ataev, A. M. Bagamadova, A. M. Djabrailov, V. V. Mamedov and R. A. Rabadanov, Highly conductive and transparent Ga-doped epitaxial $\mathrm{ZnO}$ films on sapphire by CVD, Thin Solid Films 260(1) (1995), 19-20.

DOI: https://doi.org/10.1016/0040-6090(94)09485-3

[7] V. Assuncao, E. Fortunato, A. Marques, H. Aguas, I. Ferreira, M. E. V. Costa and R. Martins, Influence of the deposition pressure on the properties of transparent and conductive $\mathrm{ZnO}$ :Ga thin-film produced by r.f. sputtering at room temperature, Thin Solid Films 427(1-2) (2003), 401-405.

DOI: https://doi.org/10.1016/S0040-6090(02)01184-7

[8] Z. F. Liu, F. K. Shan, Y. X. Li, B. C. Shin and Y. S. Yu, Epitaxial growth and properties of Ga-doped $\mathrm{ZnO}$ films grown by pulsed laser deposition, Journal of Crystal Growth 259(1-2) (2003), 130-136.

DOI: https://doi.org/10.1016/j.jcrysgro.2003.07.007

[9] H. J. Ko, Y. F. Chen, S. K. Hong, H. Wenisch, T. Yao and D. C. Look, Ga-doped ZnO films grown on GaN templates by plasma-assisted molecular-beam epitaxy, Applied Physics Letters 77(23) (2000), 3761-3763.

DOI: https://doi.org/10.1063/1.1331089

[10] T. Minami, H. Nanto and S. Takata, Highly conductive and transparent aluminum doped zinc oxide thin films prepared by RF magnetron sputtering, Japanese Journal of Applied Physics 23 Part 2(5) (1984), L280-L282.

DOI: https://doi.org/10.1143/JJAP.23.L280

[11] X.-L. Guo, H. Tabata and T. Kawai, Epitaxial growth and optoelectronic properties of nitrogen-doped $\mathrm{ZnO}$ films on (1120) $\mathrm{Al}_{2} \mathrm{O}_{3}$ substrate, Journal of Crystal Growth 237(239) (2002), 544-547.

DOI: https://doi.org/10.1016/S0022-0248(01)01974-1

[12] Y. Yan, S. B. Zhang and S. T. Pantelides, Control of doping by impurity chemical potentials: Predictions for p-type ZnO, Physical Review Letters 86(25) (2001), 5723-5726.

DOI: https://doi.org/10.1103/PhysRevLett.86.5723

[13] X. Li, Y. Yan, T. A. Gessert, C. DeHart, C. L. Perkins, D. Young and T. J. Coutts, p-Type $\mathrm{ZnO}$ thin films formed by CVD reaction of diethylzinc and $\mathrm{NO}$ gas, Electrochemical Solid-State Letters 6(4) (2003), C56-C58.

DOI: https://doi.org/10.1149/1.1554292

[14] X. Li, Y. Yan, T. A. Gessert, C. L. Perkins, D. Young, C. DeHart, M. Young and T. J. Coutts, Chemical vapor deposition-formed $p$-type $\mathrm{ZnO}$ thin films, Journal of Vacuum Science \& Technology A 21(4) (2003), 1342-1346.

DOI: https://doi.org/10.1116/1.1584036 
[15] K. Yasui, M. Morioka, S. Kanauchi, Y. Ohashi, T. Kato and Y. Tamayama, Effects of $\mathrm{N}_{2} \mathrm{O}$ gas addition on the properties of $\mathrm{ZnO}$ films grown by catalytic reactionassisted chemical vapor deposition, Journal of Vacuum Science \& Technology A 33(6) (2015); Article 061519.

DOI: https://doi.org/10.1116/1.4935334

[16] H. Umemoto, H. Kusanagi, K. Nishimura and M. Ushijima, Detection of radical species produced by catalytic decomposition of $\mathrm{H}_{2}, \mathrm{O}_{2}$ and their mixtures on heated Ir surfaces, Thin Solid Films 517(12) (2009), 3446-3448.

DOI: https://doi.org/10.1016/j.tsf.2009.01.020

[17] M. Petravic, P. N. K. Deenapanray, V. A. Coleman, C. Jagadish K.-J. Kim, B. Kim, K. Koike, S. Sasa, M. Inoue and M. Yano, Chemical states of nitrogen in $\mathrm{ZnO}$ studied by near-edge X-ray absorption fine structure and core-level photoemission spectroscopies, Surface Science 600(7) (2006), L81-L85.

DOI: https://doi.org/10.1016/j.susc.2006.01.015

[18] E.-C. Lee, Y.-S. Kim, Y.-G. Jin and K. J. Chang, Compensation mechanism for N acceptors in ZnO, Physical Review B 64(8) (2001); Article 085120.

DOI: https://doi.org/10.1103/PhysRevB.64.085120 